\title{
Preliminary Studies on Two Viruses Infecting Two Wild Plants: Talinum triangulare (Jacq) Willd and Desmodium tortuosum (SW) DC in Samaru, Zaria, Kaduna State
}

\author{
Daudu OAY ${ }^{*}$, Yusuf $\mathrm{L}^{2}$, Abejide DR ${ }^{1}$, Busari $\mathrm{J}^{1}$ and Adeniyi $\mathrm{K}^{1}$ \\ ${ }^{1}$ Department of Biological Sciences, Federal University of Technology, Minna, Nigeria \\ ${ }^{2}$ Department of Microbiology, Federal University of Technology, Akure, Nigeria
}

\begin{abstract}
In other to find an alternative hosts of virus diseases of cowpea in Zaria area, two virus disease symptoms were observed on two wild plants growing near each other at the edge of an experimental field, Department of Biological Sciences, Ahmadu Bello University, Zaria. The virus isolate in Talinum triangulare was found not to be sap transmissible in all the buffers used at different molarities and $\mathrm{pH}$ values; although the virus was found to be seed transmissible in T. triangulare, and also transmissible through grafting to healthy looking seedlings of Vigna unguiculata var. IAR-01-1006. Also symptoms were not observed in whiteflies (Bemisia tabaci) inoculated seedlings of the test plants. The virus isolate in Desmodium tortuosum, however, was found to be sap transmissible to healthy looking seedlings of $D$. Tortuosum and a number of other plant diseases, especially members of Fabaceae family. Chlorotic local lesions were observed in Chenopodium amaranticolor. $0.1 \mathrm{M}$ phosphate buffer, $\mathrm{pH} 7.4 \mathrm{was}$ found to be suitable for isolation and purification of the virus in $D$. tortuosum. The present study has also shed some light on the possible propagation host ( $V$. unguiculata var. IAR-01-1006) for T. triangulare virus isolate, a propagation and assay hosts (V. unguiculata var. IAR-01-1009 and C. amaranticolor) for D. tortuosum virus isolate. The results obtained suggested that the symptoms observed in the two wild plants were induced by two different virus isolates. It is, therefore, suggested that further studies like molecular and immunological techniques need to be carried out in order to explore more of the properties of these viruses, with the view to develop control measures; since the viruses have shown to be a potential threat to some of the most important Leguminosae crops in the area studied.
\end{abstract}

Keywords: Vigna unguiculata; Chlorotic lesions; Propagation host; Assay host; Virus diseases

\section{Introduction}

Viruses have been variously defined as any of the large group of submicroscopic infective agents that are regarded either as extremely simple microorganisms, or as extremely complex molecules, that typically contain a protein coat surrounding an RNA or DNA core of genetic materials, but no semi-permeable membrane. They are capable of growth and multiplication only in living cells, and they cause various important diseases in man, lower animals and plants [1]. Roger [2], defined viruses as obligate parasites; the infectious units comprise either RNA or DNA enclosed also have lipids in their coat. Reaction of the host is usually their only perceptible and variable effect, and even that may be lacking or invisible, as in much latent virus infection.

Viruses attack nearly all economically important crop plants. In most cases, the virus will cause reduction in yield and quality of the infected crop. Puttaraju et al. [3] reported that number of pods per plant; number of seeds per pod and 100-seed weight was significantly reduced in plants infected by Bean Common Mosaic Virus (BCMV). Castillo-Urquiza et al. [4] also reported that BMRV (Bean Rugose Mosaic Virus) caused reduction in the total weights of pods per plant. According to Ittah [5], the relationship between disease severity and yield showed that as disease severity increased, cowpea yield decreased.

Gibbs and Harrison [6], reported that in Ghana, more than 100 million cacao trees have been cut down since 1945 in attempts to stop the spread of cacao swollen shoot virus, which has mealy bugs vectors. In Citrus, the aphid-transmitted triteza virus is widespread, and in Sao Paulo state, Brazil alone, it killed 6 million trees of sweet orange, in a period of twelve years.
In 1975, groundnut rosette virus destroyed groundnut crop in the major groundnut producing areas in Nigeria [7]. Similarly, cacao swollen shoot virus drastically reduced the yields of cacao in West Africa, especially Nigeria and Ghana. Viral diseases are significantly contributing to the reduced yield of cowpea in Asia, Africa and Latin America [8].

The etiology and nature of virus disease is not well understood, this necessitated an urgent need in the control of plant virus. However, this can only be possible by the discovering of the virus properties. Viruses have long been characterized only by biological properties such as: host range, symptomatology, and mode of transmission of the virus in question.

Natural wild plants and weeds have been shown to play an important role in the occurrence and spread of plant virus in many countries, Nigeria inclusive [9]. The identification of an 'unknown' virus has been shown to involve the demonstration of a number of similarities between the unknown and a previously described virus to establish it [10]. Murphy et al. [11] said that the International Committee on the

${ }^{*}$ Corresponding author: Daudu OAY, Department of Biological Sciences, Federal University of Technology, Minna, Nigeria, E-mail: dauduoladipupoyusuf@yahoo.com

Received February 15, 2013; Accepted May 17, 2013; Published May 25, 2013

Citation: Daudu OAY, Yusuf L, Abejide DR, Busari J, Adeniyi K (2013) Preliminary Studies on Two Viruses Infecting Two Wild Plants: Talinum triangulare (Jacq) Willd and Desmodium tortuosum (SW) DC in Samaru, Zaria, Kaduna State. J Plant Pathol Microb 4: 178 doi:10.4172/2157-7471.1000178

Copyright: (c) 2013 Daudu OAY, et al. This is an open-access article distributed under the terms of the Creative Commons Attribution License, which permits unrestricted use, distribution, and reproduction in any medium, provided the original author and source are credited. 
Citation: Daudu OAY, Yusuf L, Abejide DR, Busari J, Adeniyi K (2013) Preliminary Studies on Two Viruses Infecting Two Wild Plants: Talinum triangulare (Jacq) Willd and Desmodium tortuosum (SW) DC in Samaru, Zaria, Kaduna State. J Plant Pathol Microb 4: 178 doi:10.4172/21577471.1000178

Taxonomy of Viruses (ICTV) has provided comprehensive guidelines for the identification and characterization of virus.

The common bean is the most important grain legume for direct human consumption in the world and Bean Common Mosaic Virus (BCMV) is one of the world's most serious bean diseases that can reduce yield and quality of harvested product [12]. Therefore, during the survey for the alternative hosts of virus diseases of cowpea in Zaria area, Kaduna State, Nigeria during the drying season of 2006, some light-green and dark green mosaic symptoms were observed in Talinum triangulare (Jacq) Willd and yellow mosaic symptoms observed on Desmodium tortuosum (SW) DC; both growing near each other in the experimental field in the Department of Biological Sciences experimental garden, Ahmadu Bello University, Zaria. The aim of the work is to determine some of the biological properties of the virus isolates that induced the symptoms in the wild plants mentioned earlier.

\section{Materials and Methods}

\section{Source and maintenance of virus cultures}

The original source of the viruses were naturally infected plants of Talinum triangulare and Desmodium tortuosum growing near each other in the experimental garden; Department of Biological Sciences, A.B.U., Zaria. Light-green-dark green mosaic symptoms were observed on the leaves of $T$. triangulare (Figure 1). The infected plants were propagated through stem cutting. The virus isolate was maintained on these plants throughout the study. The symptoms on the D. tortuosum were yellow mosaic colouration and distortion of the leaves (Figure 1). The symptoms were transferred onto healthy looking seedlings of the same species by mechanical inoculation using $0.1 \mathrm{M}$ phosphate buffer, pH 7.4.

\section{Transmission tests}

Seed transmission: Two hundred and fifty (250) seeds harvested from virus infected T. triangulare were raised in pots, and later transplanted into smaller pots kept in insect free cages. The plants were observed for symptoms development for a period of eight weeks.

Graft transmission: Grafting was made by cutting a stem from the infected T. triangulare (the scion) on Vigna unguiculata var. IAR-01-
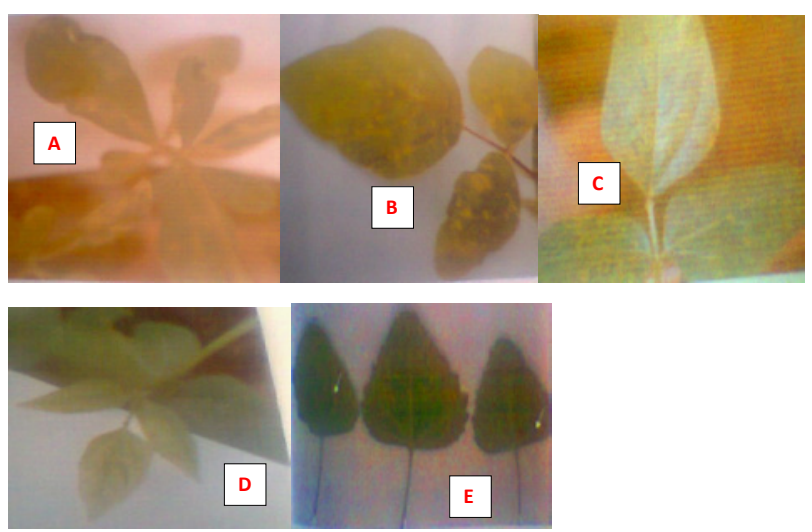

Figure 1: A: Symptoms of a naturally infected Talinum triangulare; B: Symptoms of naturally infected Desmodium tortuosum; C: Symptoms of grafted Vigna unguiculata var. IAR-01-1006 from the infected T. triangulare; D: Symptoms of mechanically inoculated Vigna unguiculata var. IAR-01-1009 from the infected $D$. tortuosum; E: Arrows indicated chlorotic local lesions in Chenopodium amaranticolor, from back test of $V$. unguiculata var. IAR-011009 , the central leaf is the control.
1006, which serves as the stock. All the leaves were removed, leaving only one. The epidermal layer was scrapped from both sides with a sterile blade. Then a slit cut was made on the stem of healthy looking cowpea seedlings. The scion was then inserted in the slit cut on stock and the joined ends were tied with self-sealing tape.

Whitefly transmission: This was carried out by Bemisiatabaci; the insects were given 10 minutes fasting before allowed acquisition feeding. A batch of fifteen (15) whiteflies was given acquisition feeding for 48 hours on infected cowpea seedlings (var. IAR-01-1006). They were then giving inoculation feeding period of 48 hours on young healthy looking seedlings of the same variety.

Mechanical inoculation: Inoculums sources for mechanical inoculation were obtained from infected waterleaf, Desmodium and cowpea. The inoculation was prepared by grinding infected young leaves displaying severe symptoms phosphate buffer solution at different $\mathrm{pH}$ values and molarities. $1 \%$ thioglycolic acid and magnesium bentonite were added to each inoculums during preparation using mortar and pestle, until a smooth homogenate were obtained. The inoculation were made by dipping sterilized rod into the inoculums and rubbing onto the expanded primary leaves of the test plants, previously dusted with carborundum, rinsed with tap water immediately after inoculation. Observations were made for symptom development between 30 and 40 days.

Host range and symptomatology: The viruses were artificially inoculated onto a number of plant species, both cultivated and wild, mainly from the family Fabaceae. Inoculums and grafting were made as previously described for mechanical inoculation and grafting. Sap inoculation was done on fully expanded leaves. 6 seedlings of each variety were used for the test. The control consisted of two seedlings inoculated with plain buffers. The inoculated plants were observed for symptoms development for a period of 36 days, and the observations were recorded.

\section{Results}

The symptom was transmissible through seeds in T. triangulare, because out of the 250 seedlings raised from the infected plants, 140 (56\%) showed symptoms similar to what was observed on the original plant. However, back inoculation to Chenopodium amaranticolor (a local lesion host) seedlings did not induce any symptom (Figure 1).

The virus was found to be transmissible through grafting from T. triangulare to a variety of cowpea (Vigna unguiculata var IAR-011006). Also, transmission was obtained from this variety to another healthy plant of the same variety, although the severity of the symptoms decreased compare to what was observed in the initial cowpea plant. Graft transmission to other cowpea varieties failed to induce symptom. No symptom was observed in the mechanically transmission, as well as whiteflies inoculated test plants.

Among the grafted cowpea varieties with infected T. triangulare, only $V$. unguiculata var IAR-01-1006 was found susceptible (Table 1), the virus systematically infected the plant. The symptom started with vein clearing on the trifoliage leaves. The interveinal area turned lightgreen giving light-green dark green mosaic pattern (Figure 1).

Both $0.1 \mathrm{M}$ phosphate buffer $\mathrm{pH} 7.4$ and 0.05 citrate buffer $\mathrm{pH} 7.4$ were found suitable for mechanical transmission of D. tortuosum. 0.1 $\mathrm{M}$ phosphate $\mathrm{pH} 7.4$ was selected based on the symptoms produced in the test plants.

Among the varieties of cowpea tested for susceptibility to the virus 
Citation: Daudu OAY, Yusuf L, Abejide DR, Busari J, Adeniyi K (2013) Preliminary Studies on Two Viruses Infecting Two Wild Plants: Talinum triangulare (Jacq) Willd and Desmodium tortuosum (SW) DC in Samaru, Zaria, Kaduna State. J Plant Pathol Microb 4: 178 doi:10.4172/21577471.1000178

\begin{tabular}{|l|c|c|}
\hline $\begin{array}{l}\text { V. unguiculata } \\
\text { varieties }\end{array}$ & $\begin{array}{c}\text { Number of seedlings with } \\
\text { symptoms }\end{array}$ & $\begin{array}{c}\text { Number of seedlings } \\
\text { grafted }\end{array}$ \\
\hline IAR-00-1074 & 0 & 6 \\
\hline IAR-01-1006 & 4 & 6 \\
\hline IAR-01-1009 & 0 & 6 \\
\hline IAR-339 & 0 & 6 \\
\hline ITAS-EALY & 0 & 6 \\
\hline
\end{tabular}

Table 1: Graft transmission of the virus isolate in T. triangulare on five varieties of cowpea.

\begin{tabular}{|l|c|c|}
\hline $\begin{array}{l}\text { V. unguiculata } \\
\text { varieties }\end{array}$ & $\begin{array}{c}\text { Number of seedlings with } \\
\text { symptoms/6 seedlings }\end{array}$ & $\begin{array}{c}\text { Reaction on } \\
\text { C. amaranticolor }\end{array}$ \\
\hline IAR-00-1074 & 0 & $*$ \\
\hline IAR-01-1006 & 0 & $*$ \\
\hline IAR-01-1009 & 3 & + \\
\hline IAR-339 & 0 & $*$ \\
\hline ITAS-EALY & 4 & + \\
\hline
\end{tabular}

Key:

$+=$ Recovery of virus

* $=$ Not tested

Table 2: Susceptibility of some cowpea varieties to infection by the virus isolate in D. Tortuosum.

isolate in D. tortuosum using sap inoculation with $0.1 \mathrm{M}$ phosphate buffer $\mathrm{pH} 7.4$; the following varieties were found susceptible, i.e. IAR01-1009 and ITAS-Ealy (Table 2). The symptoms started with vein clearing on the trifoliage leaves; the interveinal area turned light green, giving light green-dark green mosaic pattern. The inoculated leaves were assayed by back-inoculation onto $C$. amaranticolor and chlorotic lesions were produced. The symptoms appeared in the eighth day after inoculation, and were more distinct in IAR-01-1009 source than ITASEALY.

\section{Discussion}

The symptoms observed on T. triangulare and D. tortuisum were seemed to be induced by different viruses. The viruses can infect a number of plant species, especially members of the Leguminosae family. The virus in T. triangulare was seed transmissible, although seeds of the infected $V$. unguilata var IAR-01-1006 was not subjected for the seed transmission test. Many virus groups have been reported to be seed borne in cowpea plants; the cowpea mild mottle carlavirus (CMMC) transmitted by whitefly, Bemisiatabaci is seed-borne in cowpea also, a member of cucumovirus (Cucumber mosaic virus, cowpea starin (CuMV)), has also been shown to be seed-borne [13]. Seed transmission of virus depends on host genotype and virus straing; Mink [14] tabulated various seed-borne viruses in legumes worldwide. Many viruses, including those which are nematode-borne and seed transmitted, have a wide natural host range, which ensures survival in the wild, and makes them important in a wide range of annual and perennial crops [15]. The results, thus indicate the need for more investigation studies on the virus, so as to understand in details the ecology and epidemiology of the virus isolate in T. triangulare.

The result of the grafting showed that the symptoms observed on T. triangulare are not caused by environmental factor. Grafting transmission is a suitable method for studying viruses; this is because it provides a clue, as to whether the suspected symptoms are due to viral infection or environmental factor. This also implied that the virus can easily be maintained on any of the susceptible varieties through grafting, and the virus can be propagated in the variety.

The $0.1 \mathrm{M}$ phosphate buffer $\mathrm{pH} 7.4$ proved to be a better solution for isolation and purification of the virus in D. tortuosum. This is supported

by the work of Lastra and Munz [16]; Marcinka [17], who extracted a number of plant virus using phosphate buffer at molarity of $0.1 \mathrm{M}$ at varying $\mathrm{pH}$ ranging from 7.5-8.0.

Despite all the activities of the buffer on the study of infectivity of different plant viruses, the virus isolate in T. triangulare was found not to be transmissible to other plants at those molarities and $\mathrm{pH}$. This result also agreed with the findings of Thottappily [18], who noted that not all viruses can be transmitted mechanically. Gibbs and Harrison [6] also noted that viruses in nature that normally persist in the vector, such as semi-persistent and persistent aphid-transmitted viruses, and many of the leaf hopper and whitefly viruses, are not usually transmitted by sap. The above result is thus, similar to what is obtainable from most of the whiteflies transmitted pathogens, since most of them are not sap transmissible, and little is known about their particles.

\section{Conclusion}

The present study has shed some light on the possible propagation host for T. triangulare (V. unguiculata var. IAR-01-1009) and Desmodium tortuosum (V. unguiculata var. IAR-01-1009 and V. unguiculata var. ITAS-EALY); assay host for Desmodium (Chenopodium amaranticolor). The identification of $0.1 \mathrm{M}$ phosphate buffer for the purification of this virus will ZX definitely lead to the revelation of the physical and biochemical properties of the virus isolate in D. tortuosum. Further studies like molecular and immunological techniques need to be carried out in other to explore more of the properties of these viruses, with the view to develop control measures; since the viruses have shown to be a potential threat to some of the most important Leguminosae crops in the area studied.

\section{References}

1. Webster's Collegiate Dictionary (1991) Thomas Allen and Sons Limited. (9 Edn), Markham, Ontario, Canada.

2. Roger H (1992) Molecular Plant Pathology: A Practical Approach. Volume 1 Oxford University Press, London, UK.

3. Puttaraju HR, Prakash HS, Shetty HS (2004) Seed infection by Blackeye Cowpea Mosaic Potyvirus and yield loss in different cowpea varieties. J Mycol Plant Pathol 34: 41-46.

4. Castillo-Urquiza GP, Maia FG, Cavalho MG, Pinto CM, Zerbini FM (2006) Characterization of a bean rugose mosaicvirus (BRMV) isolate from Minas Gerais, and yield loss estimate in beans upon single infection and double infection with BCMV. Fitopatol Bras 31: 455-461.

5. Ittah MA (2006) Relationship between yield and some yield components in cowpea varieties infected with two cowpea potyviruses. Global Journal of Pure and Applied Sciences 12: 11-17.

6. Gibbs AJ, Harrison BD (1976) Plant Virology, the principle. Edward Arnold London, UK.

7. Yayock JT, Rossel HW, Hardness C (1976) A review of 1975 groundnut rosette epidemic in Nigeria. Conference Paper African Groundnut council symposium on 'pest' of groundnut and millet in the field held at Kaolack, Senegal.

8. Udayashankar AC, Chandra NS, Bhuvanendra KH, Mortensen CN, Shekar SH et al. (2010) Establishing inoculum threshold levels for Bean common mosaic virus strain blackeye cowpea mosaic infection in cowpea seed. Afr J Biotechno 9: 8958-8969.

9. Ekukole G, Ansa AO, Ajayi O, Sudaram NV (1989) Some grasses showing streak symptoms in samara, Zaria. J Agric Res 5: 31-35.

10. Hamilton RI, Edwardson JR, Frankci RIB, Hsu HT (1981) Molecular Plant Pathology. Oxford University Press, London, UK.

11. Murphy PA, Fauquit CM, Bishop DHL, Gnarrial SA, Arvis AW, et al. (1995) International Committee on Taxonomy of Viruses. The new classification of plant virus in families, general and species 74: 3-195.

12. Ghasemi S, Kamelmanesh MM, Namayandeh A, Biabanikhankahdani R (2011) 
Citation: Daudu OAY, Yusuf L, Abejide DR, Busari J, Adeniyi K (2013) Preliminary Studies on Two Viruses Infecting Two Wild Plants: Talinum triangulare (Jacq) Willd and Desmodium tortuosum (SW) DC in Samaru, Zaria, Kaduna State. J Plant Pathol Microb 4: 178 doi:10.4172/21577471.1000178

Page 4 of 4

Biplot analysis for evaluation of tolerance in some bean (phaseolus vulgaris I.) Genotypes to Bean Common Mosaic Virus (BCMV). World Acad Sci Eng Technol 60: 951-953.

13. Thottappilly G, Rossel HW (1996) Virus disease of cowpea in Nigeria. Tropical Pest Management 38: 337-348.

14. Mink A (1993) Seedborne diseases and their control. CAB International, UK 69-84.
15. Murant A (1983) Seedborne diseases and their control. CAB International, UK 84

16. Lastra R, Munz K (1969) Squash mosaic virus C.I.M/A.A.B. Descriptions of plant viruses Kew Surrey, England, UK 1-4.

17. Marcinka K (1991) Red Clover mottle virus C.I.M/A.A.B. Descriptions of plant viruses Kew Surrey, England, UK 1-4.

18. Thottappilly G (1992) Plant virus diseases of important to African Agriculture. J Phytopathol 134: 265-288. 